\title{
CHARACTERIZATION OF THE BENTHIC ENVIRONMENT OF A COASTAL AREA ADJACENT TO AN OIL REFINERY, TODOS OS SANTOS BAY (NE-BRAZIL)
}

\author{
Natalia Venturini ${ }^{1 *}$, Luiz Roberto Tommasi ${ }^{2}$, Márcia C. Bícego ${ }^{l}$, César C. Martins ${ }^{l}$ \\ ${ }^{1}$ Instituto Oceanográfico da Universidade de São Paulo \\ (Praça do Oceanográfico, 191, 05508-900, São Paulo, SP, Brazil) \\ ${ }^{2}$ Fundação de Estudos e Pesquisas Aquáticas (FUNDESPA) \\ (Av. Afrânio Peixoto 412, 05507-000, São Paulo, SP, Brazil)
}

\begin{abstract}
A B S T R A C T
In order to determine the sedimentological and physico-chemical characteristics of the benthic environment and also the level, distribution and probable sources of aliphatic and polycyclic aromatic hydrocarbons, sediment samples were collected at 28 stations in the northeast portion of Todos os Santos Bay. The centre and the east region of the study area showed characteristics of depositional environments with the predominance of silt and clay and high percentages of TOC, nitrogen and sulphur. The molar $\mathrm{C} / \mathrm{N}$ ratios varied between 8.8 and 27.6 indicating a mixed origin of organic matter with variable marine and continental contributions. Total aliphatic hydrocarbon concentrations ranged between 1.56 and $246.91 \mu \mathrm{g} \cdot \mathrm{g}^{-1}$ dry weight, corresponding the high concentrations to the stations situated in the centre and in the east region of the study area. The UCM represented between 60 and $96 \%$ of the total aliphatic hydrocarbons, indicating a high degree of anthropogenic contribution and the presence of petroleum degraded residues. Total PAH concentrations varied from 8 to 4163 ng. ${ }^{-1}$ dry weight. The highest total PAH concentration was recorded at station 5 situated adjacent to the oil refinery.
\end{abstract}

\section{RESUMO}

Com o intuito de determinar as características sedimentológicas e físico-químicas do ambiente bentônico e também o nível, distribuição e prováveis fontes dos hidrocarbonetos alifáticos e policíclicos aromáticos, foram coletadas amostras de sedimento em 28 estações localizadas na porção nordeste da Baía de Todos os Santos. A região central e leste da área de estudo apresentaram características de ambientes deposicionais com predomínio de silte e argila e com maiores teores de carbono orgânico total, nitrogênio e enxofre. As razões $\mathrm{C} / \mathrm{N}$ variaram entre 8,8 e 27,6 indicando uma origem mista da matéria orgânica com contribuições marinha e continental relativamente variáveis. As concentrações de hidrocarbonetos alifáticos totais variaram entre 1,56 e $246,91 \mu \mathrm{g} . \mathrm{g}^{-1}$ de sedimento seco, correspondendo as maiores concentrações às estações localizadas na região central e leste da área de estudo. A Mistura Complexa não Resolvida (UCM) representou entre 60 e $90 \%$ dos hidrocarbonetos alifáticos totais, indicando um alto grau de contribuição antrópica e a presença de resíduos de petróleo degradado. As concentrações de hidrocarbonetos policíclicos aromáticos totais variaram de 8 a 4163 ng.g ${ }^{-1}$ de sedimento seco. A maior concentração de hidrocarbonetos policíclicos aromáticos foi registrada na estação 5 situada na área adjacente à refinaria de petróleo.

Descriptors: Benthic environment; Sediments, Total organic carbon, Hydrocarbons, Oil refinery, Brazil.

Descritores: Ambiente bentônico, Sedimentos, Carbono orgânico total, Hidrocarbonetos, Refinaria de petróleo, Brasil.

\section{INTRODUCTION}

The benthic environment is a fundamental compartment within any aquatic ecosystem. Bottom sediments constitute a source of nutrients for the water column above having an important role in the benthic-

(*) Corresponding author: rulo@fcien.edu.uy Contr. No. 859 do Inst. oceanogr. da Usp. pelagic coupling and influencing primary productivity (Jørgensen, 1996). They can accumulate great amounts of organic matter affecting the oxygen content of bottom water and they are considered to be the final sink for many anthropogenic contaminants. Furthermore, marine sediments could act as a nonpoint source of contaminants causing adverse effects to organisms and to human health through trophic transfer (Hong et al., 1995). 
Coastal areas are directly subjected to anthropogenic impacts mainly derived from industrial and urban activities. Hydrocarbons present in the sediments originate from petroleum inputs, partial combustion of fossil fuels, forest fires and diagenetic degradation of biogenic precursors (Readman et al., 2002). They constitute an important amount of the organic material that reaches the sediments and also one of the most widespread sediment-associated contaminants (Bouloubassi et al., 2001). Major sources of anthropogenic hydrocarbons in the marine environment are industrial effluents, river drainage, sewage disposal, shipping operations, offshore petroleum production, and transportation (Soclo et al., 2000). Due to their high chemical stability and hidrophobicity hydrocarbons tend to adsorb on to particulate material and be deposited in the sediments, where they can accumulate to high concentrations and remain for years, particularly under anoxic conditions (Readman et al., 2002).

Todos os Santos Bay with an area of approximately $927 \mathrm{~km}^{2}$ is the largest on the Brazilian coast. It is an extensive intertidal zone that gets deeper through its centre and presents a strait at the mouth between Itaparica Island and Salvador City (Fig. 1). Water circulation within Todos os Santos Bay is principally controlled by tides, which are semidiurnal, being that high tidal currents flow towards northnortheast (NNE) and low tidal currents flow towards south-southwest (SSW) (GDB, 2000). This region is influenced by tropical climate with a well defined rainy season from April to June. During summer, predominant winds are from SE, whereas during winter they blow predominantly from NE (Ponce \& Correa, 1980).

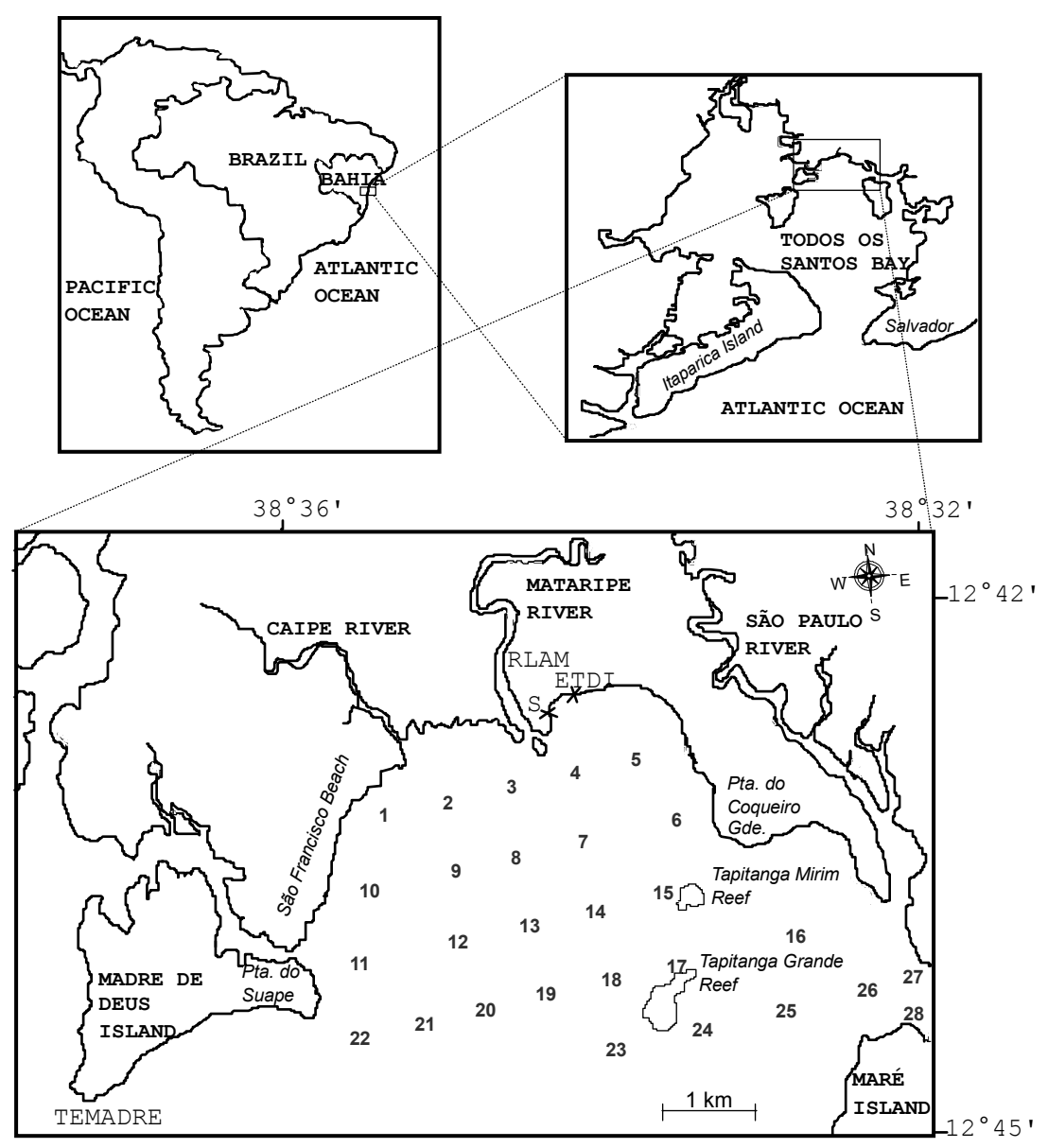

Fig. 1. Map of the northeast portion of Todos os Santos Bay, showing the 28 sampling locations. RLAM= Oil refinery, $\mathrm{S}=$ water-oil separator, ETDI= Effluent treatment station, TEMADRE= Marine terminal. 
The study area is located between $12^{\circ} 42^{\prime}$ $12^{\circ} 45^{\prime} \mathrm{S}$ and $38^{\circ} 32^{\prime}-38^{\circ} 36^{\prime} \mathrm{W}$ in the northeast portion of Todos os Santos Bay (Fig. 1). It is a shallow area with depths varying from 0.6 to $10 \mathrm{~m}$. An oil refinery of the PETROBRAS Brazilian company "Refinaria Landulpho Alves-Mataripe" (RLAM), is situated adjacent to the study area and resultant effluents are discharged into it. Three rivers flow into the northeast portion of Todos os Santos Bay, the Caípe River, the Mataripe River and the São Paulo River. All of them flow through zones with mangrove vegetation and carry wastes from several industries and urban centres (GDB, 2000).

Since 1950, the area around Todos os Santos Bay has been suffering increasing industrialisation and exploitation of its natural resources (Tavares et al., 1988). Nowadays, effluents from 29 industries drain into the bay, being responsible, together with urban and port activities, for considerable pollution problems.

The knowledge of the benthic conditions of a particular environment should contribute to the understanding of bottom dynamics, sedimentary processes and contaminant distribution patterns, and also to the interpretation of biological effects when the biota is considered.

The aim of this study was to determine the sedimentological and physico-chemical characteristics of the benthic environment in the northeast portion of Todos os Santos Bay, including the level, distribution and probable sources of aliphatic and polycyclic aromatic hydrocarbons in the sediments.

\section{Material ANd Methods}

Depth, salinity, temperature, dissolved oxygen concentration and $\mathrm{pH}$ data of bottom water were obtained using sensors coupled to a CTD.

Sediment samples were taken in August 2000 with a $0.05 \mathrm{~m}^{2}$ van Veen grab at 28 sampling locations (Fig. 1). Granulometric analyses were performed using a Laser-Mastersizer Hydro 2000 sediment analyser and parameters described by Folk \& Ward (1957) were calculated. Carbonate content was estimated as the difference between the initial weight of each sediment sample and the weight after acid attack with a $10 \% \mathrm{HCl}$ solution (Gross, 1971).

Total organic carbon, total nitrogen and sulphur were analysed using a LECO CNS 2000 analyser. Previously to be analysed, about $500 \mathrm{mg}$ of freeze-dried and weighed sediment were decarbonated with $1 \mathrm{M}$ hydrochloric acid solution, washed 3 times with deionized water and freeze-dried again.

Top centimetres $(0-2 \mathrm{~cm}$ depth) were taken from the grabs for hydrocarbons analysis. Samples were kept frozen $\left(-15^{\circ} \mathrm{C}\right)$ in aluminium containers. After drying in an oven at $50^{\circ} \mathrm{C}$ until constant weight, $25 \mathrm{~g}$ of each sediment sample were Soxhlet extracted during $8 \mathrm{~h}$ with a $50 \%$ mixture of $\mathrm{n}$-hexane and dichloromethane according to UNEP (1991). The extracts were concentrated using a rotary evaporator, desulphurised with activated cooper and fractionated by silica-alumina gel chromatography into aliphatic and aromatic hydrocarbons. Aliphatic fractions were determined by injecting $2 \mu \mathrm{l}$ of the concentrated extracts into a HP 5890A Series II gas chromatograph with a flame ionisation detector (FID). Aromatic fractions were determined by injecting $1 \mu \mathrm{l}$ of the concentrated extracts on a FISONS Trio 1000 GC/MS system, with mass detection operated under the SIM (selected ion monitoring) mode. The capillary column used was HP Ultra II $(25 \mathrm{~m}$ long, $0.32 \mathrm{~mm}$ ID, $0.25 \mu \mathrm{m}$ thickness), programmed from $40-60^{\circ} \mathrm{C}$ at $20^{\circ} \mathrm{C} \mathrm{min}^{-1}$, $60-300^{\circ} \mathrm{C}$ at $4^{\circ} \mathrm{C} \mathrm{min}^{-1}$ and held at $300^{\circ} \mathrm{C}$ for $10 \mathrm{~min}$. Quantification was performed using internal standards and the analytical program was conducted under controlled laboratory conditions, following a laboratory quality assurance protocol that includes analysis of reference material (NIST-1941), procedural blanks and participation in international intercalibration exercises. Since natural samples consist of complex hydrocarbons mixtures, different parameters in addition to absolute concentrations were analysed to evaluate the probable origin (antrhopogenic or biogenic) of hydrocarbons.

In order to determine the degree of relationship between the variables studied a nonparametric Spearman correlation analysis was performed using the computer software STATISTICA $^{\circledR}$ (StatSoft, 1995).

\section{Results AND Discussion \\ Bottom Water Characteristics}

Temperature and salinity were relatively uniform for the sampling locations, ranging from 24.1 to $25.7^{\circ} \mathrm{C}$ and from 31.6 to 32.9 , respectively (Table 1). Oxygen content of bottom water and $\mathrm{pH}$ showed a small variation among the sampling locations, being that dissolved oxygen varied between 6.37 and $7.28\left(\mathrm{mg} .1^{-1}\right)$, whereas pH showed basic values ranging from 8.61 to 8.72 . Temperature and salinity values indicated the presence of Coastal Water $(\mathrm{CW})$, which is characterised by a temperature higher than $20^{\circ} \mathrm{C}$ and a salinity that varies approximately between 32.2 and 35.4 (Castro Filho et al., 1987). 
Table 1. Depth, salinity, temperature and sedimentological variables, percentages of organic matter constituents, molar and weight ratios in the 28 sampling locations of Todos os Santos Bay.

\begin{tabular}{|c|c|c|c|c|c|c|c|c|c|c|c|c|c|c|}
\hline Sts. & Depth & Sal. & Temp. & Gravel & Sand & Silt & Clay & $\mathrm{Md}$ & $\mathrm{CaCO} 3$ & TOC & $\mathrm{N}$ & $\mathrm{S}$ & $\mathrm{C} / \mathrm{N}$ & $\mathrm{C} / \mathrm{S}$ \\
\hline & (m) & & $\left({ }^{\circ} \mathrm{C}\right)$ & $(\%)$ & $(\%)$ & $(\%)$ & $(\%)$ & (phi) & $(\%)$ & $(\%)$ & $(\%)$ & $(\%)$ & $(\mathrm{mol})$ & \\
\hline 1 & 2.1 & 31.8 & 24.4 & 0 & 99.9 & 0.1 & 0 & 2,6 & 5.0 & 0.1226 & 0.0136 & 0.0123 & 10.5 & 9.9 \\
\hline 2 & 2.5 & 31.9 & 24.3 & 0 & 95.8 & 3.2 & 1.0 & 2,1 & 18.1 & 0.1349 & 0.0100 & 0.0246 & 15.8 & 5.5 \\
\hline 3 & 1.8 & 31.6 & 24.5 & 0 & 99.8 & 0.2 & 0 & 2,5 & 4.1 & 0.1900 & 0.0191 & 0.0206 & 11.6 & 9.2 \\
\hline 4 & 1.7 & 31.7 & 25.6 & 0 & 90.9 & 7.8 & 1.3 & 2,8 & 3.3 & 0.3355 & 0.0283 & 0.0892 & 13.9 & 3.8 \\
\hline 5 & 2.0 & 31.7 & 25.5 & 0 & 8.4 & 66.3 & 25.3 & 6,6 & 5.8 & 3.5171 & 0.2629 & 1.0425 & 15.7 & 3.4 \\
\hline 6 & 2.7 & 32.2 & 25.5 & 0 & 7.5 & 73.0 & 19.4 & 6,5 & 54.0 & 0.6665 & 0.0859 & 0.4581 & 9.1 & 1.5 \\
\hline 7 & 1.9 & 31.9 & 25.2 & 0 & 77.7 & 17.1 & 5.2 & 2,6 & 89.6 & 0.4537 & 0.0470 & 0.1118 & 11.2 & 4.1 \\
\hline 8 & 3.0 & 31.9 & 24.3 & 0 & 10.3 & 74.9 & 14.7 & 6,2 & 7.4 & 2.4630 & 0.2569 & 1.3478 & 11.2 & 1.8 \\
\hline 9 & 4.3 & 32.2 & 24.1 & 0 & 8.7 & 78.6 & 12.6 & 6,2 & 76.2 & 0.8880 & 0.0891 & 0.4621 & 11.6 & 1.9 \\
\hline 10 & 2.3 & 31.8 & 24.6 & 9.4 & 90.4 & 0.2 & 0 & 1,5 & 34.2 & 0.1766 & 0.0107 & 0.0225 & 19.4 & 7.9 \\
\hline 11 & 1.6 & 31.9 & 24.7 & 0 & 6.8 & 71.1 & 22.1 & 6.6 & 42.9 & 0.2558 & 0.0225 & 0.0724 & 13.3 & 3.5 \\
\hline 12 & 4.5 & 32.2 & 24.1 & 0 & 8.2 & 77.4 & 14.3 & 6.3 & 9.1 & 2.1070 & 0.2037 & 1.2978 & 12.1 & 1.6 \\
\hline 13 & 4.8 & 32.5 & 24.7 & 0 & 4.3 & 69.1 & 26.6 & 6.8 & 8.8 & 1.9463 & 0.2133 & 0.6167 & 10.6 & 3.2 \\
\hline 14 & 3.0 & 31.9 & 24.4 & 0 & 5.4 & 67.9 & 26.7 & 6.8 & 5.7 & 2.8741 & 0.2504 & 1.2079 & 13.5 & 2.4 \\
\hline 15 & 1.7 & 32.0 & 25.3 & 8.8 & 91.0 & 0.1 & 0 & 0.8 & 93.2 & 0.1479 & 0.0121 & 0.0155 & 14.3 & 9.5 \\
\hline 16 & 3.0 & 32.1 & 25.3 & 0 & 10.3 & 70.8 & 18.8 & 6.4 & 15.6 & 1.4393 & 0.1738 & 0.1504 & 9.7 & 9.6 \\
\hline 17 & 1.1 & 32.3 & 25.6 & 57.3 & 42.6 & 0.2 & 0 & 0.5 & 88.7 & 0.1840 & 0.0165 & 0.0200 & 13.1 & 9.2 \\
\hline 18 & 2.2 & 32.5 & 25.7 & 0 & 6.4 & 73.5 & 20.1 & 6.6 & 36.3 & 1.4696 & 0.1523 & 0.4152 & 11.2 & 3.5 \\
\hline 19 & 5.7 & 32.8 & 24.6 & 0 & 1.5 & 75.6 & 22.8 & 6.9 & 11.6 & 1.3364 & 0.1774 & 0.0980 & 8.8 & 13.6 \\
\hline 20 & 7.5 & 32.9 & 24.8 & 0 & 3.4 & 71.5 & 25.1 & 6.8 & 6.0 & 1.4755 & 0.1829 & 0.1706 & 9.5 & 8.6 \\
\hline 21 & 9.0 & 32.3 & 24.4 & 0 & 6.9 & 71.7 & 21.3 & 6.6 & 5.5 & 2.1000 & 0.2428 & 0.5466 & 10.1 & 3.8 \\
\hline 22 & 2.3 & 31.9 & 24.5 & 30.5 & 69.4 & 0.1 & 0 & 0.3 & 90.6 & 0.1855 & 0.0217 & 0.0159 & 10.1 & 11.7 \\
\hline 23 & 1.3 & 32.5 & 25.7 & 0 & 89.1 & 8.2 & 2.6 & 1.3 & 67.8 & 0.2974 & 0.0251 & 0.0649 & 13.8 & 4.6 \\
\hline 24 & 1.2 & 32.4 & 25.3 & 21.4 & 78.5 & 0.1 & 0 & 0.3 & 77.2 & 0.1855 & 0.0187 & 0.0162 & 11.6 & 11.5 \\
\hline 25 & 3.3 & 31.8 & 25.2 & 0 & 6.9 & 65.1 & 27.4 & 6.7 & 10.6 & 1.4542 & 0.1800 & 0.1198 & 9.5 & 12.1 \\
\hline 26 & 1.1 & 31.8 & 25.4 & 0 & 20.6 & 57.7 & 21.7 & 6.0 & 2.4 & 3.3628 & 0.1423 & 1.1951 & 27.6 & 2.8 \\
\hline 27 & 1.3 & 31.9 & 24.9 & 0 & 14.8 & 66.6 & 18.6 & 6.2 & 1.9 & 1.6578 & 0.1756 & 0.4704 & 11.0 & 3.5 \\
\hline 28 & 3.3 & 31.9 & 25.3 & 0 & 90.5 & 7.2 & 2.3 & 3.0 & 0 & 0.2824 & 0.0207 & 0.0768 & 15.9 & 3.7 \\
\hline
\end{tabular}

$\mathrm{Sal} .=$ salinity, $\mathrm{Temp} .=$ temperature, $\mathrm{Md}=$ mean diameter, $\mathrm{TOC}=$ total organic carbon, $\mathrm{N}=$ total nitrogen, $\mathrm{S}=$ sulphur.

Sediment Composition and Distribution

Sand was the predominant sediment fraction at stations 1, 2, 3, 4, 7, 10, 15, 17, 22, 23, 24 and 28 with percentages between 42.6 and $99.9 \%$ (Table 1). These stations showed lower mean diameter (phi) than the others. Silt and clay content ranged from 0.1 to $78.6 \%$ and from 0 to $27.4 \%$, respectively, being the high values recorded at stations $5,6,8,9,11,12,13$, $14,16,18,19,20,21,25,26$ and 27 (Table 1). Figure 2 presents the distribution maps of sand, silt and carbonate in the study area. Silt and clay (map not shown) presented the same distribution pattern and they were positive correlated $(\mathrm{p}<0.05)$ (Table 2). Sediment distribution is associated with hydrodynamic conditions near the bottom. Coarse sediments tend to be deposited in areas with high hydrodynamic energy, whereas fine sediments tend to be deposited in areas with low hydrodynamic energy (Suguio, 1973). The dominance of muddy sediments in the centre and the east region of the study area can be associated with low energy levels. In contrast, sand predominated at the most inner stations (1, 2, 3 and 4) directly influenced by the inflow of the Caípe River and the Mataripe River, where bottom dynamic is supposed to be high (Fig. 2). The high percentage of sand recorded also at stations $10,15,17,22,23,24$ and 28 could be related to wave erosion on proximate sources such as the São Francisco Beach and the rocky substrates of Pta. do Suape and Pta. do Coqueiro Grande. In coastal 

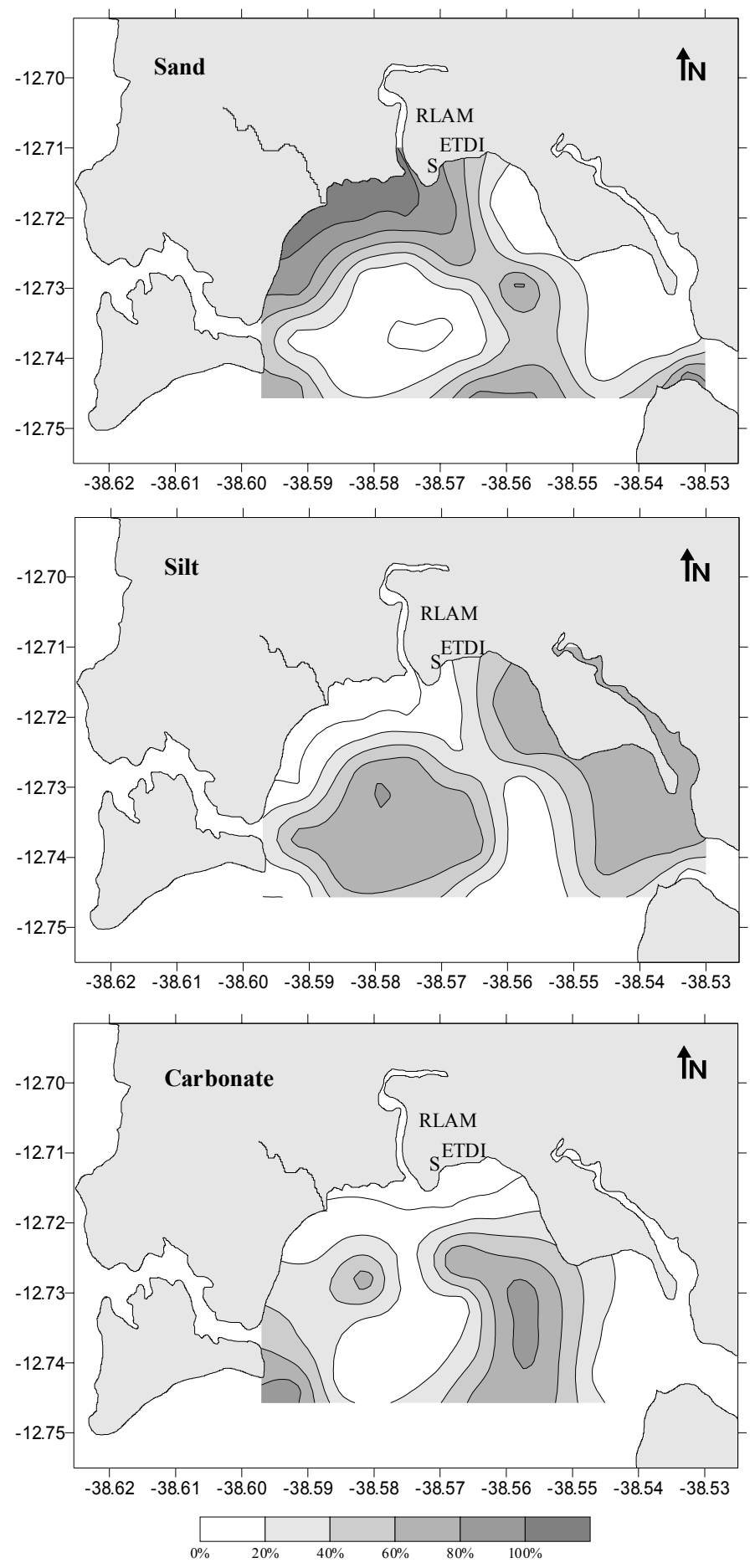

Fig. 2. Maps showing the distribution pattern of sand, silt and carbonate in the northeast portion of Todos os Santos Bay. 
Table 2. Nonparametric correlation results between the variables studied. Significant $(\mathrm{p}<0.05)$. Spearman correlation coefficients in bold.

\begin{tabular}{|c|c|c|c|c|c|c|c|c|c|c|c|c|}
\hline & $\begin{array}{l}\text { Depth } \\
\text { (m) }\end{array}$ & $\begin{array}{l}\text { Sand } \\
(\%)\end{array}$ & $\begin{array}{l}\text { Silt } \\
(\%)\end{array}$ & $\begin{array}{l}\text { Clay } \\
(\%)\end{array}$ & $\begin{array}{c}\mathrm{CaCO}_{3} \\
(\%)\end{array}$ & $\begin{array}{l}\text { TOC } \\
(\%) \\
\end{array}$ & $\begin{array}{l}\mathrm{N} \\
(\%) \\
\end{array}$ & $\begin{array}{l}\mathrm{S} \\
(\%)\end{array}$ & $\mathrm{C} / \mathrm{N}$ & $\mathrm{C} / \mathrm{S}$ & $\begin{array}{l}\Sigma \text { aliph } \\
\left(\mu \mathrm{g} \mathrm{g}^{-1}\right)\end{array}$ & $\begin{array}{l}\Sigma \mathrm{PAH} \\
\left(\mathrm{ng} \mathrm{g}^{-1}\right)\end{array}$ \\
\hline Depth (m) & 1 & & & & & & & & & & & \\
\hline Sand $(\%)$ & -0.536 & 1 & & & & & & & & & & \\
\hline Silt (\%) & 0.578 & -0.776 & 1 & & & & & & & & & \\
\hline Clay (\%) & 0.452 & -0.864 & 0.689 & 1 & & & & & & & & \\
\hline $\mathrm{CaCO}_{3}(\%)$ & -0.173 & 0.014 & -0.118 & -0.307 & 1 & & & & & & & \\
\hline TOC (\%) & 0.358 & -0.683 & 0.699 & 0.797 & -0.438 & 1 & & & & & & \\
\hline $\mathrm{N}(\%)$ & 0.486 & -0.746 & 0.732 & 0.799 & -0.361 & 0.946 & 1 & & & & & \\
\hline S (\%) & 0.397 & -0.650 & 0.772 & 0.737 & -0.374 & 0.958 & 0.904 & 1 & & & & \\
\hline $\mathrm{C} / \mathrm{N}$ & -0.469 & 0.489 & -0.359 & -0.302 & -0.094 & -0.156 & -0.354 & -0.121 & 1 & & & \\
\hline $\mathrm{C} / \mathrm{S}$ & -0.992 & 0.283 & -0.565 & -0.356 & 0.255 & -0.582 & -0.462 & -0.748 & -0.269 & 1 & & \\
\hline$\Sigma$ aliph $\left(\mu \mathrm{g} \mathrm{g}^{-1}\right)$ & 0.102 & -0.343 & 0.615 & 0.373 & -0.159 & 0.661 & 0.565 & 0.736 & 0.046 & -0.649 & 1 & \\
\hline$\sum$ PAH $\left(\right.$ ng g $\left.^{-1}\right)$ & 0.351 & -0.473 & 0.452 & 0.645 & -0.430 & 0.726 & 0.702 & 0.704 & -0.122 & -0.359 & 0.490 & 1 \\
\hline
\end{tabular}

TOC $=$ total organic carbon, $\mathrm{N}=$ total nitrogen, $\mathrm{S}=$ sulphur, $\Sigma$ aliph $=$ total aliphatic hydrocarbons, $\Sigma$ PAH $=$ total polycyclic aromatic hydrocarbons.

areas wave action plays a fundamental role in the bottom sedimentary processes (Furtado \& Mahiques, 1989). The progressive mechanic erosion produced by wave action results in the fragmentation of rocky substrates and with the posterior reduction, reworking and transport of these fragments, in the formation of sand particles (Leinz \& Amaral, 1985).

Carbonate content in the sediments varied from 0 to $93.2 \%$ with values higher than $30 \%$ at stations $6,7,9,10,11,15,17,18,22,23$ and 24 (Table 1). The distribution map showed two different deposits of carbonate, one localised to the west and the other to the east of the study area (Fig. 2). It is known, that biogenic debris are important constituents of marine sediments. Our results showed that the deposit situated westwards was constituted mainly by shell fragments, probably derived from organisms of the rocky substrate of Pta. do Suape. Coral fragments derived from the Tapitanga Grande Reef and from the Tapitanga Mirim Reef, indicating a high marine influence in this zone, constituted the other deposit situated eastwards.

As was mentioned before, water circulation within Todos os Santos Bay is principally controlled by tides (GDB, 2000). In a previous work, Ponce and Correa (1980) concluded that sediment composition in the west portion of the bay could be attributed to tidal currents dynamic. In the study area sediment composition and distribution seem to be related not only with tidal currents dynamic but also with the interaction between river and marine inputs.
Total Organic Carbon, total Nitrogen and Sulphur, $\mathrm{C} / \mathrm{N}$ and $\mathrm{C} / \mathrm{S}$ ratios

Total organic carbon (TOC) ranged from 0.1226 to $3.5171 \%$, the high contents were found at those stations with high percentage of silt and clay (Table 1). Organic matter distribution is affected by hydrodynamic conditions and related to the granulometric composition of the sediments. The distribution map of TOC showed that the high values occurred at the stations localised in the centre and in the east region of the study area (Fig. 3) with reduced hydrodynamic energy, and associated with the dominance of fine sediment fractions. The positive correlation $(p<0.05)$ between the percentage of silt, clay and the total organic carbon content in the sediments confirm this trend (Table 2). This is not surprising, considering that the adsorption of dissolved organic matter by suspended clay particles is very important in the extraction of organic matter from water and in its incorporation in bottom sediments (Bordovskiy, 1965). Furthermore, the rate of production and preservation of marine organic carbon and the input of terrestrial organic carbon are the main factors responsible for the organic enrichment of marine sediments (Sánchez et al., 1999). The Caípe, Mataripe and the São Paulo rivers flow through zones with mangrove vegetation; therefore, great amounts of suspended organic matter are expected to enter in the study area carried by the flux of these three rivers. 

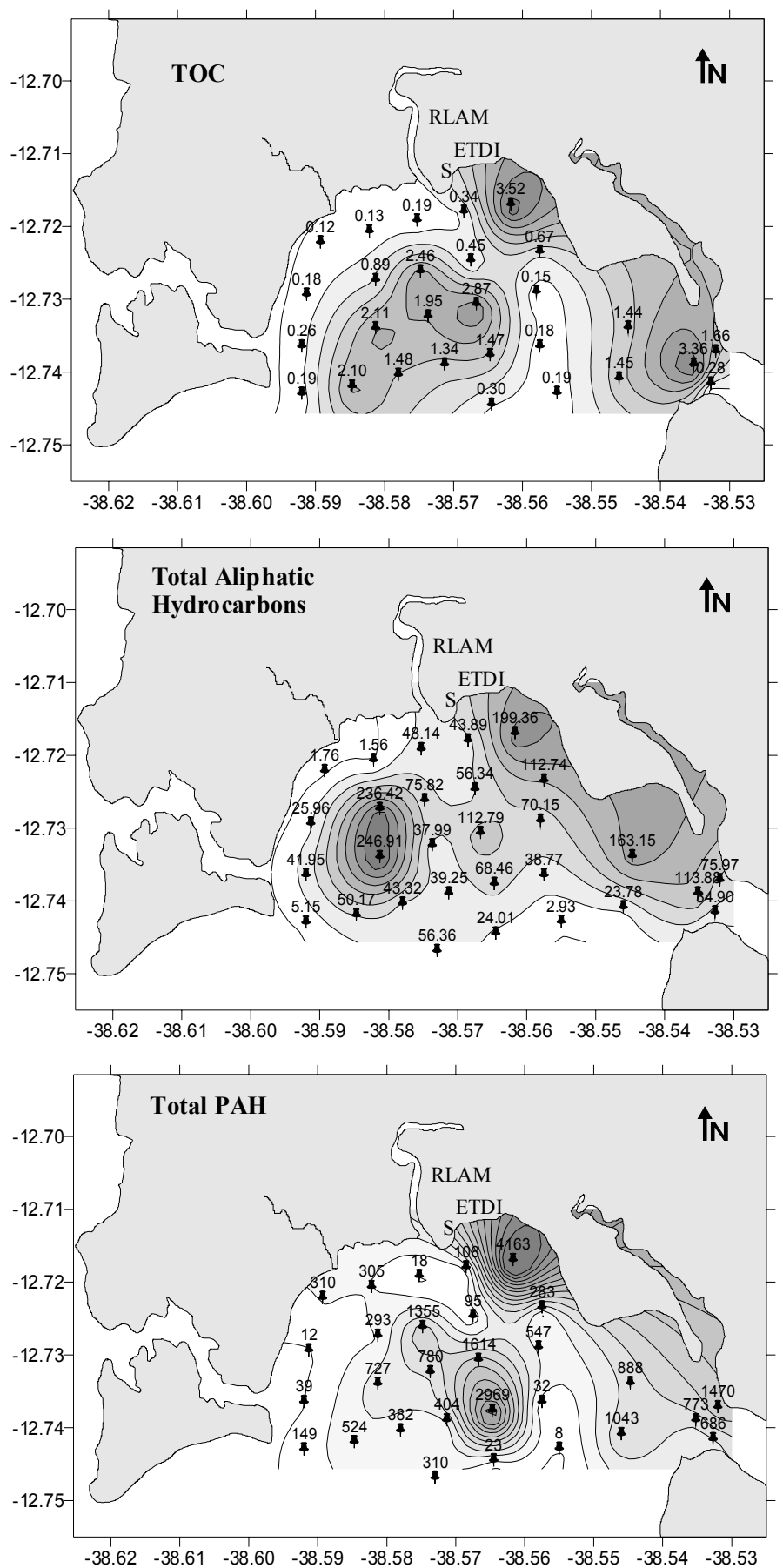

Fig. 3. Maps showing the distribution pattern of total organic carbon (TOC), total aliphatic hydrocarbons ( $\mu \mathrm{g} \cdot \mathrm{g}^{-1}$ dry weight) and total polycyclic aromatic hydrocarbons (PAH) (ng. $\mathrm{g}^{-1}$ dry weight), in the northeast portion of Todos os Santos Bay. 
Total nitrogen and sulphur varied between 0.01 and $0.2629 \%$ and between 0.0123 and $1.3478 \%$, respectively (Table 1), both presented the same distribution pattern of TOC (maps not shown). Total nitrogen and sulphur contents were positively correlated $(p<0.05)$ with the organic carbon content in the sediments as well as with the percentage of silt and clay (Table 2). Moreover, total nitrogen and TOC showed the high values at the same stations $5,8,12$, 13, 14, 16, 18, 19, 20, 21, 25, 26 and 27 (Fig. 4a). The same distribution pattern and the positive correlation observed between total nitrogen and total organic carbon in the northeast portion of Todos os Santos Bay could be related to the fact that nitrogen-containing compounds are an important part of organic matter (Stein, 1991). For that reason, it could be expected that nitrogen content and its distribution in relation to particle size, be similar to the organic carbon distribution. However, part of the nitrogen can be inorganic, fixed in the form of ammonia to the mineral skeleton of the sediments and not directly related to the organic matter (Bordovskiy, 1965). Since we measured total nitrogen, this should be taken into account for the correct interpretation of the results.

Carbon-nitrogen molar ratios $(\mathrm{C} / \mathrm{N})$ varied between 8.8 and 27.6 (Table 1). The composition of organic matter in the sediments is complex. The $\mathrm{C} / \mathrm{N}$ ratios can be used to infer the origin and the sources of organic matter because different groups of organisms produced organic matter with different TOC and N contents (Stein, 1991). According to Saito et al. (1989) $\mathrm{C} / \mathrm{N}$ ratios higher than 20 suggest a terrestrial source and $\mathrm{C} / \mathrm{N}$ ratios between 5 and 7 a pelagic source. Moreover, Stein (1991) suggested that values around 10 indicate both marine and continental contributions. For most of the stations in the northeast portion of Todos os Santos Bay, the $\mathrm{C} / \mathrm{N}$ ratios observed seem to indicate a mixed origin of organic matter with variable marine and continental contributions. This variability in the $\mathrm{C} / \mathrm{N}$ ratios is common in semi-enclosed and shallow environments, owing to the mixed nature of organic matter (Bordovskiy, 1965). In addition, the high $\mathrm{C} / \mathrm{N}$ ratios observed at stations $2,5,10,26$ and 28 , suggested the presence in the sediments of organic matter depleted in nitrogen derived from terrestrial plants, woody detritus and petroleum products (McGroddy \& Farrington, 1995).

Carbon-sulphur weight ratios $(\mathrm{C} / \mathrm{S})$ varied from 1.5 to 13.6 and the low values were found at stations $6,8,9,12,14$ and 26 (Table 1). Leventhal (1983) and Berner (1989) stated that the relationship between the organic carbon and sulphur content $(\mathrm{C} / \mathrm{S})$ could help to distinguish between an oxygenated and an anoxic environment. According to these authors $\mathrm{C} / \mathrm{S}$ ratios lower than 2.8 are indicative of sediments with a trend to anoxic conditions. Our results demonstrated a general tendency to oxygenated conditions excepting at stations $6,8,9,12,14$ and 26.

\section{Aliphatic Hydrocarbons}

Total aliphatic hydrocarbon concentrations ranged between 1.56 and $246.91 \mu \mathrm{g} . \mathrm{g}^{-1}$ dry weight, corresponding the high concentrations to the stations situated in the centre and in the east region of the study area (Fig. 3). Concentrations of total aliphatic hydrocarbons in unpolluted intertidal and estuarine sediments are normally lower than $10 \mu \mathrm{g} \cdot \mathrm{g}^{-1}$ (UNEP, 1991; Volkman et al., 1992). In organically enriched sediments, when there is a significant input of nalkanes derived from higher plants, total aliphatic hydrocarbon concentrations may reached values up to $100 \mu \mathrm{g} \cdot \mathrm{g}^{-1}$. However, values higher than this such as those recorded at stations 5, 6, 9, 12, 14, 16 and 26 (Fig. 4b), are indicative of petroleum inputs (Volkman et al., 1992). Moreover, total aliphatic hydrocarbon concentrations detected in this study are similar to those recorded in other highly contaminated areas on the Atlantic coast of South America (e.g. Nishigima et al., 2001; Muniz et al., 2003). Total n-alkanes concentrations ranged from 0.86 to $39.94 \mu \mathrm{g} . \mathrm{g}^{-1}$ (Table $3)$. Alkanes with odd-chains between $n-\mathrm{C}_{25}$ and $n$ - $\mathrm{C}_{33}$, which are one of the principal constituents of the epicular wax of the mangrove vegetation leaves, predominated (Eglinton et al., 1962). The positive correlation $(p<0.05)$ between total organic carbon and total aliphatic hydrocarbons (Table 2 ) could be related to the input of terrestrial plant materials, as well as, to the input of petroleum products (McGroddy \& Farrington, 1995). In general, petroleum shows no predominance of odd or even carbon chains, although, long chain n-alkanes from plant inputs can often obscure the petroleum derived n-alkane signal (Volkman et al., 1992). The Carbon Preference Index (CPI) showed values around 1 at stations 1, 2, 3, 8, 9, $11,13,17,18,19$ and 21 suggesting the presence of petrogenic hydrocarbons (Table 3).

The concentrations of resolved aliphatic hydrocarbons were between 1.56 and $104.75 \mu \mathrm{g} . \mathrm{g}^{-1}$ and the values of the unresolved complex mixture (UCM) varied from non-detected to $189.01 \mu \mathrm{g} . \mathrm{g}^{-1}$ (Table 3). According to Commendatore et al. (2000) the occurrence of the unresolved complex mixture (UCM) and its magnitude are related to the presence of degraded oil and the degree of anthropogenic contribution. In most of the stations of the northeast portion of Todos os Santos Bay the UCM represented between 60 and $96 \%$ of the total aliphatic hydrocarbons, which is indicating a high degree of anthropogenic contribution and the presence of petroleum degraded residues. The UCM was not detected only at stations 1, 2, 22 and 24 (Table 3). The sum of the resolved aliphatic/unresolved complex 
mixture index (Res/UCM) showed the high values at stations $5,9,13,14,25$ and 26 suggesting also, the presence of fresh oil (Table 3), whereas in the reminder stations low values indicated mainly the occurrence of degraded oil (Commendatore et al., 2000).

Although the isoprenoid pristane $\left(\mathrm{C}_{19}\right)$ is present in petroleum, it has a biogenic origin and is also present in the biota as a degradation product of the phytol, a component of the chlorophyll- $a$ chain. The isoprenoid phytane $\left(\mathrm{C}_{20}\right)$ can occur as a result of diagenetic processes, rarely has a biogenic origin and is a common component of crude oil (Steinhauer \& Boehm, 1992; Volkman et al., 1992). It is relevant to remark that at stations 1,2, 22 and 24, phytane was not detected (Table 3). The absence of phytane, of UCM and the fact that the stations mentioned above showed the low total aliphatic hydrocarbon concentrations within the study area (Fig. 4b), may be related to a less petroleum contribution at these locations.

Polycyclic Aromatic Hydrocarbons (PAH)

Total PAH concentrations in surface sediments of the northeast portion of Todos os Santos Bay varied from 8 to 4163 ng.g $^{-1}$ dry weight, being that they were similar to those recorded in other coastal regions that receive important anthropogenic inputs derived from urban and industrial activities (e.g. Kim et al., 1999; Soclo et al., 2000; Muniz et al., 2002). The maximum value was found at station 5 situated adjacent to the oil refinery (Fig. 4b). Stations $5,8,12,13,14,15,16,18,21,25,26,27$ and 28 showed total PAH concentrations higher than 500 ng. $\mathrm{g}^{-1}$ (Fig. 4b), which is indicative of relatively highly contaminated samples (Notar et al., 2001). The distribution map showed that high total PAH

a)

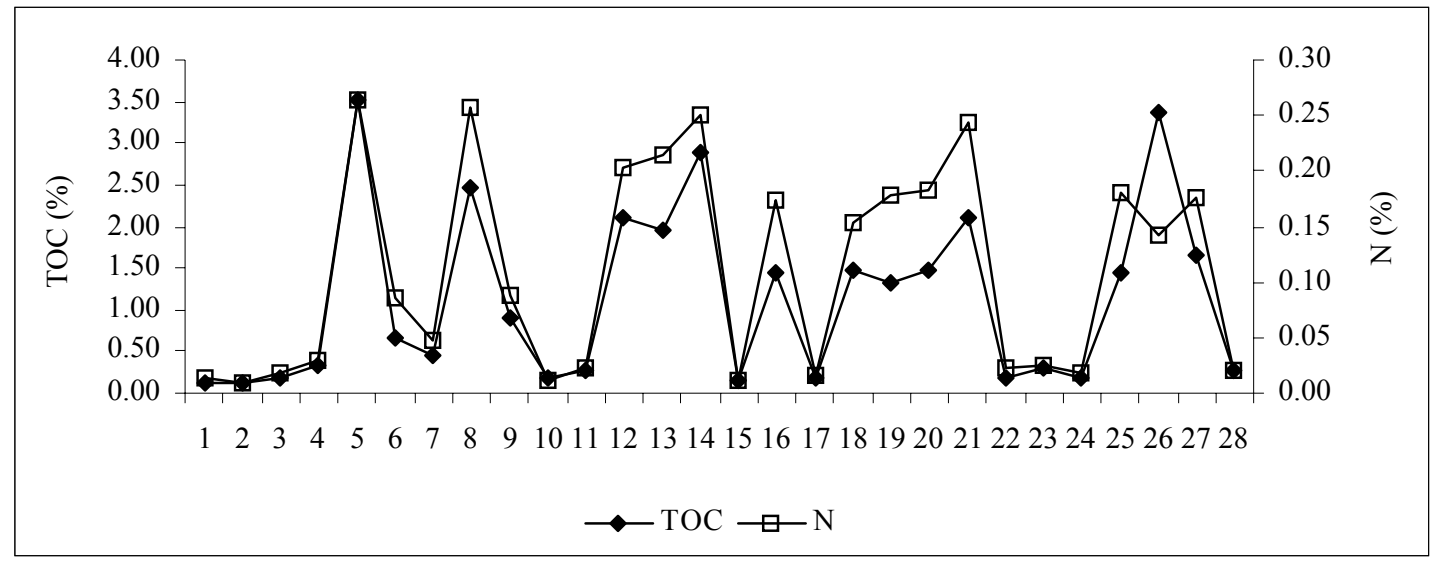

b)

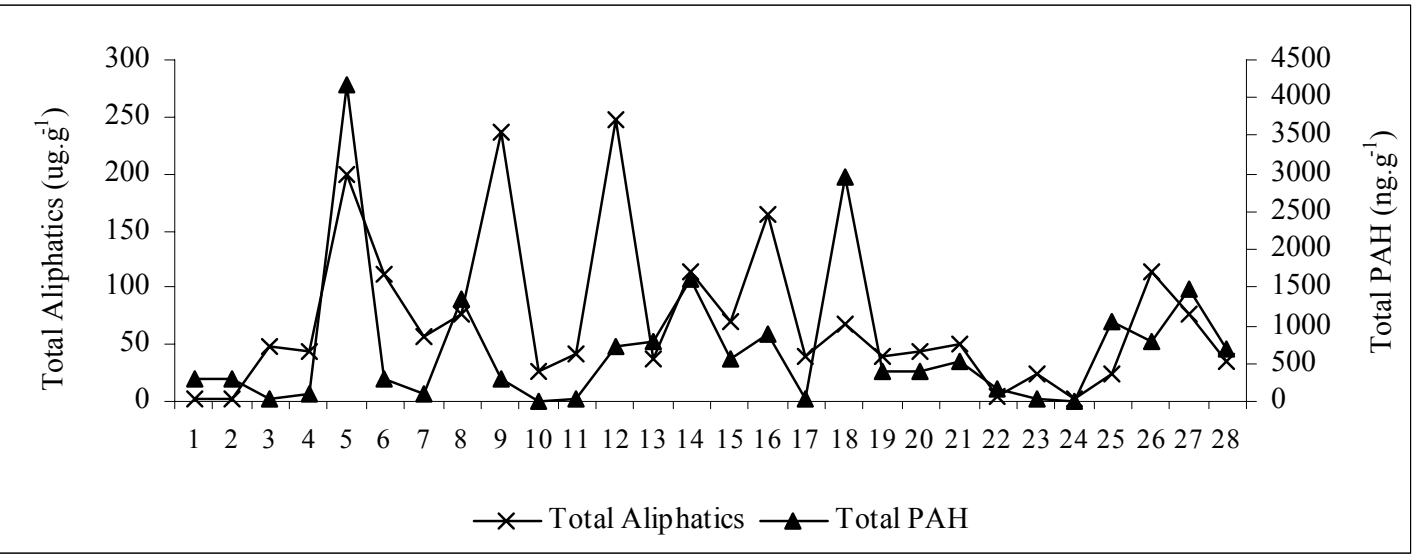

Fig. 4. Total organic carbon (TOC), total nitrogen (N), total aliphatic hydrocarbons ( $\mu \mathrm{g} \mathrm{g}^{-1}$ dry weight) and total polycyclic aromatic hydrocarbons concentrations in sediment samples of the 28 stations. 
Table 3. Concentration (in $\mu \mathrm{g} \cdot \mathrm{g}^{-1}$ dry weight) of total n-alkanes, UCM, pristane, phytane and resolved aliphatic hydrocarbons in sediment samples of Todos os Santos Bay. Values of the evaluation indices applied for aliphatic and polycyclic aromatic hydrocarbons.

\begin{tabular}{|c|c|c|c|c|c|c|c|c|c|c|c|c|}
\hline Sts. & $\sum$ n-alk. & $\mathrm{UCM}$ & $\begin{array}{c}\% \\
\mathrm{UCM}\end{array}$ & Pri & Phy & Res aliph. & $\mathrm{CPI}$ & $\begin{array}{c}\text { Res aliph./ } \\
\text { UCM }\end{array}$ & Flth/Pyr & Phe/Anth & $\begin{array}{c}\Sigma \text { alkylnaph/ } \\
\text { Naph }\end{array}$ & LMW/HMW \\
\hline 1 & 0.86 & n. d. & - & 0.09 & n. d. & 1.76 & 1.01 & - & 1.00 & - & 0.10 & 0.61 \\
\hline 2 & 1.15 & n. d. & - & 0.05 & n. d. & 1.56 & 1.05 & - & 0.95 & - & 0.09 & 0.37 \\
\hline 3 & 2.74 & 40.05 & 83 & 0.22 & 0.09 & 8.09 & 1.12 & 0.20 & 0.29 & - & 0.21 & 0.35 \\
\hline 4 & 6.42 & 35.72 & 81 & 0.17 & 0.31 & 8.16 & 0.72 & 0.23 & 0.29 & 5.10 & 0.51 & 0.81 \\
\hline 5 & 14.12 & 119.70 & 60 & 0.35 & 0.03 & 79.66 & 2.16 & 0.67 & 0.28 & 0.25 & 4.74 & 1.49 \\
\hline 6 & 8.04 & 93.68 & 83 & 0.29 & 0.10 & 19.06 & 0.83 & 0.20 & 0.93 & 3.52 & 1.36 & 0.14 \\
\hline 7 & 6.35 & 40.32 & 72 & 0.93 & 0.16 & 16.02 & 0.71 & 0.40 & 0.49 & 1.85 & 0.31 & 0.24 \\
\hline 8 & 2.46 & 50.96 & 67 & n. d. & 0.10 & 24.86 & 1.00 & 0.49 & 1.19 & 0.19 & 4.06 & 0.21 \\
\hline 9 & 6.82 & 131.67 & 56 & 0.93 & 0.14 & 104.75 & 1.51 & 0.80 & 0.75 & 0.56 & 1.81 & 0.32 \\
\hline 10 & 1.73 & 22.97 & 89 & n. d. & n. d. & 2.98 & 0.56 & 0.13 & 0.56 & - & - & 0.25 \\
\hline 11 & 1.57 & 36.96 & 88 & 0.24 & 0.03 & 4.98 & 1.71 & 0.13 & - & - & 8.77 & 0.35 \\
\hline 12 & 5.83 & 189.01 & 77 & 0.42 & 0.43 & 57.89 & 0.44 & 0.31 & 1.00 & 0.50 & 4.13 & 0.37 \\
\hline 13 & 5.33 & 18.31 & 48 & 0.22 & 0.17 & 19.68 & 1.35 & 1.07 & 0.87 & 0.54 & 10.81 & 0.42 \\
\hline 14 & 5.93 & 55.22 & 49 & 0.11 & 0.18 & 57.56 & 2.45 & 1.04 & 0.10 & 0.40 & 9.08 & 0.37 \\
\hline 15 & 8.65 & 67.67 & 96 & 0.60 & 0.63 & 2.48 & 0.70 & 0.04 & 0.78 & 61.25 & 0.10 & 1.89 \\
\hline 16 & 8.15 & 143.84 & 88 & 0.10 & 0.04 & 19.32 & 2.09 & 0.13 & 1.05 & 23.23 & 1.32 & 0.23 \\
\hline 17 & 5.22 & 33.52 & 86 & 0.29 & 0.16 & 5.25 & 1.25 & 0.16 & 0.25 & - & 1.35 & 0.21 \\
\hline 18 & 7.93 & 49.09 & 72 & 0.43 & 0.25 & 19.37 & 1.03 & 0.39 & 1.37 & 3.86 & 0.52 & 0.98 \\
\hline 19 & 5.47 & 26.95 & 69 & 1.06 & 0.11 & 12.30 & 1.57 & 0.46 & 1.77 & 2.42 & 3.27 & 0.25 \\
\hline 20 & 6.05 & 29.30 & 68 & 0.87 & 0.05 & 14.02 & 0.52 & 0.48 & 0.94 & 1.10 & 2.30 & 0.34 \\
\hline 21 & 9.63 & 31.61 & 63 & 1.92 & 1.66 & 18.56 & 1.18 & 0.59 & 0.80 & 1.08 & 2.68 & 0.29 \\
\hline 22 & 3.16 & n. d. & - & 0.19 & n. d. & 5.15 & 5.84 & - & 2.09 & - & 0.04 & 0.02 \\
\hline 23 & 1.14 & 21.43 & 89 & 0.20 & n. d. & 2.58 & 0.19 & 0.12 & 1.23 & - & - & 0.25 \\
\hline 24 & 1.38 & n. d. & - & 0.72 & n. d. & 2.93 & 11.45 & - & 1.17 & - & - & 0.24 \\
\hline 25 & 15.17 & 6.27 & 26 & n. d. & n. d. & 17.51 & 0.22 & 2.79 & 1.78 & 11.84 & 1.29 & 0.80 \\
\hline 26 & 39.94 & 57.09 & 50 & 1.52 & 0.15 & 56.79 & 3.01 & 0.99 & 0.78 & 1.33 & 0.16 & 0.24 \\
\hline 27 & 3.78 & 63.24 & 83 & n. d. & 0.08 & 63.24 & 0.62 & 0.20 & 0.64 & 11.15 & 0.33 & 0.43 \\
\hline 28 & 1.93 & 25.56 & 73 & n. d. & 0.04 & 25.56 & 2.52 & 0.37 & 0.78 & 18.30 & 0.24 & 0.60 \\
\hline
\end{tabular}

$\mathrm{CPI}=$ carbon preference index based on Aboul-Kassim and Simonet (1996), Res aliph./UCM = resolved aliphatic hydrocarbons/UCM ratio. Flth/Pyr $=$ fluoranthene/pyrene ratio, ratio, $\mathrm{LMW}=\mathrm{PAHs}$ with three and four aromatic rings, $\mathrm{HMW}=\mathrm{PAHs}$ with five and six aromatic rings, not calculated $=$

concentrations, as well as high total aliphatic hydrocarbon concentrations were found in the centre and in the east region of the study area, where muddy sediments predominated (Fig. 3). Total PAH concentration was positive correlated $(\mathrm{p}<0.05)$ with the organic carbon content in the sediments (Table 2). The distribution pattern of PAH and the positive correlation between total PAH concentration and the organic carbon content in the sediments, could be explained by the low solubility and high hydrophobicity of $\mathrm{PAH}$, and their tendency to adsorbed to organic matter and to accumulate in fine sediments (Law \& Biscaya, 1994). Several studies have demonstrated that organic matter plays the most important role in the adsorption of PAH in marine sediments (e.g. Chin \& Gschwend, 1992; Chiou et al., 1998). Furthermore, among other organic particles, terrestrial plant material detritus presented in the study area, could act as both sources and favourable adsorption matrices of $\mathrm{PAH}$ in the sediments (Wang et al., 2001). Most of the stations showed fluoranthene/pyrene ratios (Flth/Pyr) $<1$ and 
phenanthrene/anthracene ratios (Phe/Ant) $<10$ that are suggesting both pyrolytic and petrogenic sources of PAH (Soclo et al., 2000; Readman et al., 2002). The ratio between the lower molecular weight $\mathrm{PAH}$ with three and four aromatic rings and the higher molecular weight PAH with five and six aromatic rings (LMW/HMW) was $<1$ at all stations, excepting at stations 5 and 15 (Table 3). The dominance of higher molecular weight PAH in the sediment samples of the northeast portion of Todos os Santos Bay could be related to the slow degradation and high persistence of these compounds (Readman et al., 1982). The dominance of alkylated homologs of naphthalene $(\Sigma$ alkylnaph/Naph $>1$ ) at station 5 situated near the oil refinery and at the stations localised in the centre and in the east region of the study area (Sts. 6, 8, 9, 11, 12, $13,14,16,17,19,20,21$ and 25) was indicative of fresh petroleum sources (Table 3). According to Law \& Biscaya (1994) in the proximity of direct oil inputs such as production platforms and refineries, it is common to find high concentrations of alkylated PAH.

In summary, the sedimentary structure of the northeast portion of Todos os Santos Bay seems to be related with both tidal currents dynamic and the interaction between river and marine inputs. The centre and the east region showed characteristics of depositional environments with the predominance of silt and clay and the high total organic carbon, total nitrogen and sulphur contents. On the other hand, sand predominated at the most inner stations (1, 2, 3 and 4) directly influenced by the inflow of the Caípe River and the Mataripe River. The molar $\mathrm{C} / \mathrm{N}$ ratios showed a mixed origin of organic matter with variable marine and continental contributions. The weight $\mathrm{C} / \mathrm{S}$ ratios showed a general tendency to oxygenated conditions excepting at stations $6,8,9,12,14$ and 26. Although n-alkanes of biogenic origin characteristic of plant waxes predominated, the occurrence and the high magnitude of the UCM indicated a high degree of petroleum hydrocarbons contribution. Stations 5,8 , $12,13,14,15,16,18,21,25,26,27$ and 28 showed total PAH concentrations higher than $500 \mathrm{ng} . \mathrm{g}^{-1}$, indicating a relatively highly contamination of these samples. The highest total PAH concentration was recorded at station 5 situated adjacent to the oil refinery. In general, the indices used to evaluate the probable sources of hydrocarbons showed the occurrence of petrogenic contamination with some pyrolytic input and with the presence of degraded or weathered petroleum in the sediments of the northeast portion of Todos os Santos Bay.

\section{ACKNOWLEDGEMENTS}

The colleagues of the FUNDESPA (Fundação de Estudos e Pesquisas Aquáticas) are acknowledged for their help in different stages of this work. The Conselho Nacional de Desenvolvimento Científico e Tecnológico (CNPq) of the Brazilian Government is acknowledged for the MSc scholarship to N. Venturini. This work was developed within the project "Diagnóstico Ambiental Marinho da Área de Influência da Refinaria Landulpho Alves, Mataripe, Baía de Todos os Santos" a partnership between the FUNDESPA and the PETROBRAS (Petróleo do Brasil, SA). One anonymous referee is acknowledged for his comments that contributed to the improvement of this manuscript.

\section{REFERENCES}

Berner, R. A. 1989. Biogeochemical cycles of carbon and sulfur and their effect on atmospheric oxygen over Phanerozoic time. Paleogeogr. Paleoclimatol. Paleoecol., 75:97-122.

Bordovskiy, O. K. 1965. Accumulation of organic matter in bottom sediments. Mar. Geol., 3:33-82.

Bouloubassi, I.; Fillaux, J. \& Saliot, A. 2001. Hydrocarbons in Surface Sediments from the Changjiang (Yangtze River) Estuary, East China Sea. Mar. Pollut. Bull., 42: 1335-1346.

Castro Filho, B. M.; Miranda, L. B. \& Miyao, S. Y. 1987. Condições hidrográficas na plataforma continental ao longo de Ubatuba: variações sazonais e em média escala. Bolm Inst. Oceanogr., S Paulo, 35(2):135-151.

Chin, Y. P. \& Gschwend, P. M. 1992. Partitioning of polycyclic aromatic hydrocarbons to marine porewater organic colloids. Environ. Sci. Technol., 26:1621-1626.

Chiou, C. T.; McGroddy, S. E. \& Kile, D. E. 1998. Partitioning characteristics of polycyclic aromatic hydrocarbons on soils and sediments. Environ. Sci. Technol., 32:264-269.

Commendatore, M. G.; Esteves, J. L. \& Colombo, J. C. 2000. Hydrocarbons in Coastal Sediments of Patagonia, Argentina: Levels and Probable Sources. Mar. Pollut. Bull., 11:989-998.

Eglinton, G.; Gonzalez, A.; Hamilton, R. J. \& Raphael, R. 1962. Hydrocarbons constituents of wax coating of plant leaves. A taxonomy survey. Phytochemistry, 1:89-109.

Folk, R. L. \& Ward, W. C. 1957. Brazos River Bar: a study in the significance of grain size parameters. J. sedim. Petrology, 27:3-26.

Furtado, V. V. \& Mahiques, M. M. 1989. Distribution of sediments in the northern coast and continental shelf of the State of São Paulo. In: SYMPOSIUM OF ECOSYSTEMS OF THE SOUTHERN AND SOUTHEASTERN BRAZILIAN COAST. Águas de Líndoia, SP. Proceedings. São Paulo, Academy of Science of the State of São Paulo, 1:20-29.

Gross, M. G. 1971. Carbon Determination. In: Carver, R. E. ed., Procedures in Sedimentary Petrology. New York, Wiley-Interscience. p. 573-596.

Hong, H.; Xu, L.; Zhang, L.; Chen, J. C.; Wong, Y. S. \& Wan, T. S. M. 1995. Environmental fate and chemistry of organic pollutants in the sediment of Xiamen and Victoria Harbours. Mar. Pollut. Bull., 31:229-236.

Jørgensen, B. 1996. Material flux in the sediment. In: Jørgensen, B. \& Richardson, K. eds. Coastal and estuarine studies. American Geophysical Union. p.115135 . 
Kim, G. B.; Maruya, K. A.; Lee, R. F.; Lee, J. H.; Koh, C. H. \& Tanabe, S. 1999. Distribution and sources of polycyclic aromatic hydrocarbons in sediments from Kyeonggi Bay, Korea. Mar. Pollut. Bull., 38:7-15.

Law, R. J. \& Biscaya, J. L. 1994. Polycyclic aromatic hydrocarbons (PAH)-Problems and progress in sampling, analysis and interpretation. Mar. Pollut. Bull., 29:235241.

Leinz, V. \& do Amaral, S. E. 1985.Geologia Geral. $9^{a}$ ed. São Paulo, Editora Nacional. 397p.

Leventhal, J. S. 1983. An interpretation of carbon and sulfur relationships in Black Sea sediments as indicators of environments of deposition. Geochim. cosmochim. Acta., 47: 133-137.

McGroddy, S. E. \& Farrington, J. W. 1995. Sediment porewater partitioning of polycyclic aromatic hydrocarbons in three cores from Boston Harbor, Massachusetts. Environ. Sci. Technol., 29:1542-1550.

Muniz, P.; Venturini, N. \& Martinez, A. 2002. Physicochemical characteristics and pollutants of the benthic environment in the Montevideo coastal zone, Uruguay. Mar. Pollut. Bull., 44:962-968.

Muniz, P.; Danulat, E.; Yannicelli, B.; García-Alonso, J.; Medina, G. \& Bícego, M. C. 2003. Assessment of contamination by heavy metals and petroleum hydrocarbons in sediments of Montevideo Harbour (Uruguay). Environ. Int., 29:1019-1028.

Nishigima, F. N.; Weber, R. R. \& Bícego, M. C. 2001. Aliphatic and aromatic hydrocarbons in sediments of Santos and Cananéia, SP, Brazil. Mar. Pollut. Bull., 42: 1064-1072.

Notar, M.; Leskovsek, H. \& Faganeli, J. 2001. Composition, distribution and sources of Polycyclic aromatic hydrocarbons in sediments of the Gulf of Trieste, northern Adriatic Sea. Mar. Pollut. Bull., 42:36-44.

Ponce, V. R. \& Correa, C. I. 1980. Contribuição à sedimentologia da Baía de Todos os Santos-Parte Leste. Anais Hidrogr., 37:113-139.

Readman, J. W.; Mantoura, R. F. C.; Rhead, M. M. \& Brown, L. 1982. Aquatic distribution and heterotrophic degradation of polycyclic aromatic hydrocarbons (PAH) in the Tamar estuary. Estuar. coastal Shelf. Sci., 14:369389 .

Readman, J. W.; Fillmann, G.; Tolosa, I.; Bartocci, J.; Villeneuve, J. P.; Catinni, C. \& Mee, L. D. 2002. Petroleum and PAH contamination of the Black Sea Mar. Pollut. Bull., 44: 48-62.

Saito, Y.; Nishimura, A. \& Matsumoto, E. 1989. Transgressive sand sheet covering the shelf and upper slope off Sendai, Northeast Japan. Mar. Geol., 89:245258
Sánchez-Mata, A.; Glémarec, M. \& Mora, J. 1999. Physicochemical structure of the benthic environemnt of a Galician ría (Ría de Ares-Betanzos, north-west Spain). J. mar. biol. Ass. UK., 79: 1-21.

Soclo, H. H.; Garrigues, P. H. \& Ewald, M. 2000. Origin of polycyclic aromatic hydrocarbons (PAHs) in coastal marine sediments: case studies in Cotonou (Benin) and Aquitaine (France) Areas. Mar. Pollut. Bull., 40: 387396.

StatSoft Inc. 1995. STATISTICA for the windows operating system. Release 5. Tulsa, EUA, Statsoft, Inc.,

Stein, R. 1991. Accumulation of organic carbon in marine sediments. Results from Deep Sea Drilling Project/ocean Drilling Program. In: Bhattacharji, S., Friedman, G.M., Neugebauer, H.J., Seilacher, A. eds. Lectures Notes in Earth Sciences. Berlin, Springer, 34v. 217p.

Steinhauer, M. S. \& Boehm, P. D. 1992. The composition and distribution of saturated and aromatic hydrocarbons in nearshore sediments, river sediments, and coastal peat of the Alaskan Beaufort Sea: implications for detecting anthropogenic hydrocarbon inputs. Environ. Res., $33: 223-253$

Suguio, K. 1973. Introdução à sedimentologia. São Paulo, Edgard Blücher/EDUSP. 317p.

Tavares, T. M.; Roch, V. C.; Porte, C.; Barceló, D. \& Albaigés, J. 1988. Application of the Mussel Watch concept in studies of hydrocarbons, PCBs and DDT in the Brazilian Bay of Todos os Santos (Bahia). Mar. Pollut. Bull., 19:575-578.

UNEP (United Environment Programme). 1991. Determinations of petroleum hydrocarbons in sediments. Reference methods for marine pollution studies. 97p.

Volkman, J. K.; Holdsworth, D. G.; Neill, G. P. \& Bavor Jr., H. J. 1992. Identification of natural, anthropogenic and petroleum hydrocarbons in aquatic sediments. Sci. Total Environ., 112:203-219.

Wang, X. C.; Zhang, Y. X. \& Chen, R. F. 2001. Distribution and partitioning of polycyclic aromatic hydrocarbons (PAHs) in different size fractions in sediments from Boston Harbor, United States. Mar. Pollut. Bull., 11:1139-1149.

(Manuscript reiceved 05 August 2003; revised 26 April 2004; accepted 07 May 2004) 